\title{
DIFFERENCES BETWEEN REGULAR AND DISTANCE EDUCATION IN A TEACHER'S TRAINING PROGRAM
}

\author{
Giannakoudakis Zacharias [giannakoudakisæ@gmail.com],Giossos Yiannis [ygiossos@phed.uoa.gr], School of \\ Physical Education and Sport Science, National and Kapodistrian University of Athens, Ethnikis Antistasis \\ 41, Dafni, 17237, Greece, [http:// wmw.phed.noa.gr]
}

\begin{abstract}
The aim of this research was to study the differences in social presence and autonomy concerning the two methods of education used in a training program for science teachers in the years 2015-2016. The first method was the traditional face to face and the other was the Distance Education method. In particular, the study focused on whether there are differences in the social presence and autonomy between the two teaching methods, and the teaching experience of the participants. A closed-type questionnaire of Likert type was used to collect the data, while $t$-test for independent samples was used for statistical analysis. The study indicated differences in the social presence and autonomy between the two methods of teaching.
\end{abstract}

\section{Abstract in Greek}

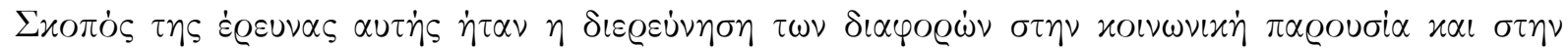

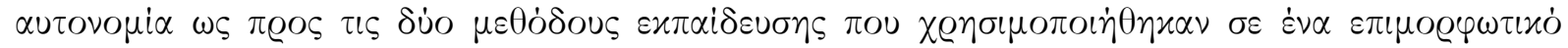

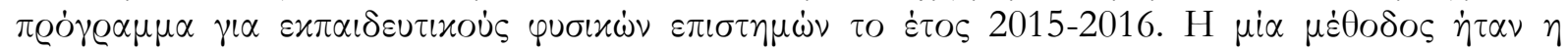

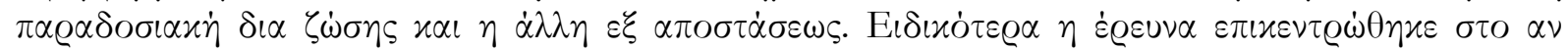

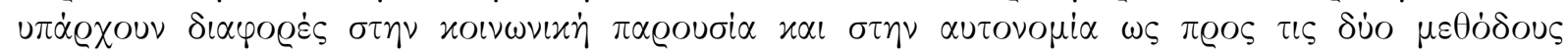

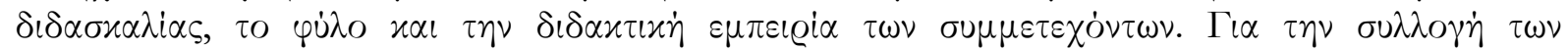

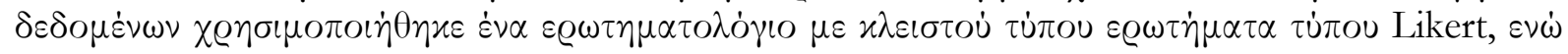

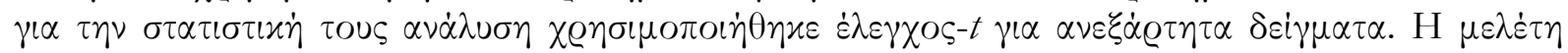

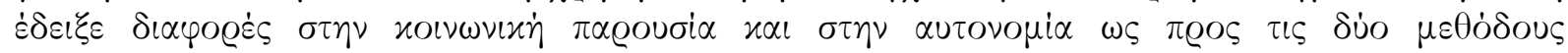

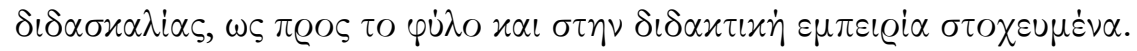

Key-words: distance education, social presence, autonomy, adult learners

\section{Introduction}

The concepts of social presence and autonomy are fundamental in the study of distance education (Anderson \& Dron, 2011). This study investigates the social presence and autonomy in two distinctive groups of teachers who attended a training program, where each group was trained using a different educational method, in particular, the face-to-face education method and the distance education method from the Laboratory Centers of Physical Sciences (GSEE). As this was more of an instructional or educational program, this study uses the terms education, edification and training as synonymous terms, even though in effect they have a different meaning. During the last few years, a part of the program is being carried out using the distance education method, but what remains under investigation is, whether the autonomy of the trainee teachers is enhanced, as well as whether the trainee teachers and their instructors operate in a collaborative environment where the sense of social presence is growing.

The student's autonomy is one of the major challenges in distance education, since its development allows teaching to meet the real education needs of the individuals (Shearer, 2007). 
Although the concept of autonomy has been studied under various perspectives, in an attempt of a general assessment, which certainly wouldn't cover all aspects, one could define autonomy as the transfer of the learning responsibility to the student, as he is the only one who can adjust both the rate and the frequency of the learning process (Benson, 2007). The significance of the concept of autonomy is ascertained by Hiemstra (2004, as mentioned in Giagli, Giaglis, \& Koutsouba, 2010) but also by a theoretical approach in distance education by Delling, Wedemeyer, and Moore (Keegan, 1996; 2001; Simonson, Smaldino, \& Albri, 2008; Paulsen, 1993; Falloon, 2011).

In Greece, there are numerous studies on student's autonomy in a distance education programs (e.g. Tsitlakidou, 2011; Giagli, Giaglis \& Koutsouba, 2010; Arvanitis, 2007; Chartofilaka, 2007; Dalakou, 2005; Lazakidou-Kafetzi, Paraskevas, \& Retalis, 2004; Anastasiadi, 2004; Lionarakis, 2004; Fotiadou, 2001), and even more abroad (e.g. Moore, 2016; Firat, 2016; Balaban-Sali, 2008; Shearer, 2007; Moore \& Kearsley, 2005; Li, Lee, \& Kember, 2000; Peters, 2001). Therefore, one may say that autonomy in distance education has been broadly studied both in Greece and abroad. The first study of autonomy in distance education programs for teachers in Greece was performed by Kastanou, Petropoulos, and Roussi (2004). Later, studies for the training staff of the Second Chance Schools were published by Papastamati et al., (2010) and Karava (2014) whose study dealt with the pedagogical principles, the material and the basic principles of online multimedia learning as a part of a training program. Abroad, and especially in the last decade, the literature review identified Gillies's (2008) study which focused on teachers-to-be and how they perceive teaching approaches, through their active participation, as prerequisites for learning, Andrade's study (2015) which emphasized the creation of strong foundations in the learning community and the autonomy of the trainee, and Sibgatullina's (2015) study where the training of foreign language teachers through Multimedia Language Labs (MLL) is being investigated.

The social presence is an essential element for the development of collaboration and dialogue in distance learning environments (Garrison \& Anderson, 2003). The basic elements that frame social presence are emotional expression, group coherence and open communication that we also study in our own survey (Garrison, Anderson, \& Archer, 2000). Thus, especially in the field of distance education, the lack of social presence repels communication amongst the individuals, and leads to feelings of impersonal interaction and disengagement from learning (Kear, 2010). Many researchers concentrated on the factors affecting social presence (e.g. Masino, 2015; Sung \& Mayer, 2012; Baker, 2010; Hron et al., 2007, as mentioned in Mouzakis \& Balaouras, 2009; Lombard et al., 2000; Schubert, Friedmann, \& Regenbrecht, 1999; Witmer \& Singer, 1998; Lombard \& Ditton, 1997; Steuer, 1992).

There are a number of studies on the social presence of students in distance education (e.g. Antoniou, Volioti, \& Stylianidis, 2012; Paraskeva \& Psyllou, 2009; Angelaki \& Mavroidis, 2013; Tsiotakis \& Tzimogannis, 2014; Mouzakis, Vathi, \& Gogoulou, 2014; So \& Brush, 2008, as mentioned by Noteboom \& Claywell, 2010; Richardson \& Swan, 2003; Gunawardena \& Zittle, 1997; Christophel \& Gorham, 1995; Christophel, 1990; Moore, Masterson, Christophe, \& Shea, 1996). More specifically, regarding research on the social presence of students in distance education training programs, the study of Ghamdi, Samarji and Watt (2016), which brings the effectiveness of the teacher out, should be pointed up; Themeli's and Bougia's work (2016), where the question whether teachers can improve communication and enhance it by using visual contact with the distance learners in the training process, was raised and studied. In a more practical level, researches such as Rovai's (2002), and Akcaoglu and Lee (2016) studied ways of enhancing social presence relative to the size of the group, as well as Kozan's (2016) study, where an attempt to associate cognitive presence with social presence was carried out. 
In our research, social presence was defined as the sense of teamwork, participation, interaction and communication of the participants in the training program and autonomy as the ability of a participant to manage his time and procedures in studying.

\section{Research questions}

1. Whether there were differences between the two teaching methods in the social presence and autonomy.

2. Whether there were differences between the two teaching methods in the social presence and autonomy regarding a) the men's group of trainees and b) the women's group of trainees.

3. Whether there were differences between the two teaching methods in the social presence and autonomy within each group with different teaching experience.

4. Whether there were differences between the two teaching methods in the social presence and autonomy within each group with different level of studies.

\section{Methods}

The research approach preferred was the Causal Comparative Research (Ex post facto research) and inferences were drawn studying the degree of rigor in controlling the conditions during the research conducted (Korres, 2007; Cohen, Manion, \& Morrison, 2008). The sample of the survey was made up by 205 teachers (96 men and 109 women) who serve the Secondary Education around Greece, in the Physics field and who attended the Fluid Mechanics training courses during the year 2015-2016 from the Laboratory Centers of Physical Sciences (GSEE), divided into two groups. The first group followed the regular educational method while the second one the distance learning method. Both programs had the same duration, subject matter and educational material. The sampling method was that of the provided sample (Creswell, 2011; pp.243-248).

In the distance learning program, there was a video demonstrating the material and the learners could execute the procedure in a virtual activity platform. The learners could borrow the material from the educators so as to use it in their school units or on their own. Communication between the group members was through a number of web tools, such as a forum, chat rooms, blogs, wikis and e-mail. On the other hand, the face-to-face group watched the educators demonstrating the procedure and then divided into teams of 4-5 people to execute the procedure experientially. As in the previous group, it was possible for all learners of this group to get the material for school or personal use.

In order to assess the social presence, the strategy of selecting individual questions from five available questionnaires was decided (Driver, 2002; Bray et al., 2008; Barnard et al., 2009; Nowak \& Biocca, 2003; Basdogan et al., 2000). That is because none of them covered the total set of factors of social presence postulated by the bibliography and refer to the sense of teamwork, interaction, collaboration and communication (Kear, 2010; Smith, 2007; Lombard et al., 2000; Garrison et al., 2000; Steuer, 1992), factors used to measure social presence. Thus, the questionnaire's content validity of was ensured but its construct validity was a clear limitation in this research. The questions targeting the investigation of social presence were nine (9) Likert type, with five levels of agreement/disagreement. Cronbach's alpha in this research was .879 for social presence.

As far as the assessment of autonomy is concerned, using the exact same way of thinking, the strategy of selecting individual questions from two discrete studies (Barnard et al., 2009; Bray et al., 2008) was preferred. This decision ensures covering the total set of autonomy factors were 
involved in this study. In particular, and according to the bibliography, autonomy focuses on factors related to the self-regulating learning over learning time and rate of learning, the in-depth understanding of the training material and the flexibility in involvement (Andrade, 2015; Gillies, 2008; Offir et al., 2008; Keegan, 2001; Hurd et al., 2001; Tam, 2000), factors used to measure social presence. The questions targeting the investigation of the trainees' autonomy degree were eight (8) Likert type, with five levels of agreement/disagreement. The overall questionnaire was forwarded online after the completion of both the distance learning and the regular programs. Cronbach's alpha in this research was .921 for autonomy.

Lastly, for statistical data analysis, descriptive statistical indicators have been used (mean values, standard deviation and variance) and $t$-test for independent samples (Creswell, 2011; pp.341,367).

\section{Results}

205 people took part in the survey, out of which 96 people or $46.8 \%$ were men and 109 or $53.3 \%$ were women. Out of the total respondents, 123 people or $60 \%$ attended the regular educational method seminar, while 82 people or $40 \%$ attended the seminar under the distance learning procedure. The reliability of the social presence scale was measured using Cronbach alpha (a) and was found to be .879 , while the autonomy scale index was .921. On average trainers experienced social presence $(M=3.44, S D=.75, B C a 95 \% C I[3.34,3.55])$ as well as autonomy $(M=3.14$, $S D=.97, B C a 95 \%$ CI $[3.01,3.27])$.

\section{$1^{\text {st }}$ research question}

On average, trainers in the distance educational method experienced greater social presence $(M=3.75, S D=.87, B C a 95 \% C I[3.55,3.92])$ than of trainers in the regular educational method $(M=3.25, S D=.59, B C a 95 \% C I[3.14,3.35])$. This difference $(.50 B C a 95 \% C I[-.71,-.28])$ was statistically significant $t(129)=-4.55, p=.00$ and represented a medium-sized effect $d=.67$. The mean value of the trainees' autonomy in the regular method was $M=2.56, S D=.69, B C a 95 \%$ $C I[2.43,2.68]$ and that of the trainees in the distance educational method was $M=4.02$, $S D=.63, B C a 95 \% C I$ [3. 90, 4.14]. This difference of $-1.46 B C a 95 \% C I[-1.64,-1.28]$ was statistically significant $t(203)=-15.77, p=.00$ and represented a large effect size $d=2.60$.

\section{$2^{\text {nd }}$ research question}

In the second research question we searched for differences within the group of men and within the group of women about the two methods of teaching about social presence and autonomy.

Table 1

\begin{tabular}{|c|c|c|c|c|c|c|c|c|}
\hline \multirow{3}{*}{ Social presence of men } & Method & $\mathrm{M}$ & SD & BCa $95 \% \mathrm{Cl}$ & $\mathrm{t}$ & $\mathrm{df}$ & $p$ & $d$ \\
\hline & Regular & 3.26 & .67 & $3.09,3.43$ & \multirow{2}{*}{-4.771} & \multirow{2}{*}{94} & \multirow{2}{*}{.000} & \multirow{2}{*}{.97} \\
\hline & Distance & 3.95 & .74 & $3.68,4.16$ & & & & \\
\hline \multirow[t]{2}{*}{ Autonomy of men } & Regular & 2.60 & .78 & $2.42,2.81$ & \multirow{2}{*}{-9.233} & \multirow{2}{*}{94} & \multirow{2}{*}{.000} & \multirow{2}{*}{1.94} \\
\hline & Distance & 4.01 & .67 & $3.78,4.20$ & & & & \\
\hline \multirow[t]{2}{*}{ Social presence of women } & Regular & 3.24 & .53 & $3.10,3.37$ & \multirow{2}{*}{-2.205} & \multirow{2}{*}{107} & \multirow{2}{*}{.05} & \multirow{2}{*}{.52} \\
\hline & Distance & 3.56 & .96 & $3.25,3.85$ & & & & \\
\hline \multirow[t]{2}{*}{ Autonomy of women } & Regular & 2.52 & 61 & $2.38,2.68$ & \multirow{2}{*}{-13.46} & \multirow{2}{*}{107} & \multirow{2}{*}{.05} & \multirow{2}{*}{2.70} \\
\hline & Distance & 4.03 & .50 & $3.86,4.18$ & & & & \\
\hline
\end{tabular}

\section{$3^{\text {rd }}$ research question}

The teaching experience of the participants was split into four categories. In the first one, there were those who had experience of up to 6 years, in the second those who had experience from 7 
to 12 years, in the third those who had experience from 13 to 20 years and in the fourth the rest of the participants. The t-test was used to check into the differences between the two teaching methods within each class of teaching experience.

Table 2

\begin{tabular}{|c|c|c|c|c|c|c|c|c|}
\hline \multirow{3}{*}{ Social p. of 0-6 year } & Method & $M$ & SD & $\mathrm{BCa} 95 \% \mathrm{Cl}$ & $\mathrm{t}$ & $d f$ & $p$ & $d$ \\
\hline & Regular & 3.04 & .75 & $2.59,2.51$ & \multirow{2}{*}{-3.873} & \multirow{2}{*}{25} & \multirow{2}{*}{.05} & \multirow{2}{*}{1.50} \\
\hline & Distance & 4.07 & .62 & $3.76,4.34$ & & & & \\
\hline \multirow[t]{2}{*}{ Auto. of 0-6 year } & Regular & 2.40 & .75 & $2.02,2.99$ & \multirow{2}{*}{-7.168} & \multirow{2}{*}{25} & \multirow{2}{*}{.000} & \multirow{2}{*}{2.71} \\
\hline & Distance & 4.14 & .51 & $3.89,4.36$ & & & & \\
\hline \multirow[t]{2}{*}{ Social p. of 7-12 year } & Regular & 3.20 & .58 & $3.00,3.39$ & \multirow{2}{*}{-2.011} & \multirow{2}{*}{57} & \multirow{2}{*}{.05} & \multirow{2}{*}{.54} \\
\hline & Distance & 3.55 & .72 & $3.23,3.85$ & & & & \\
\hline \multirow[t]{2}{*}{ Auto. of 7-12 year } & Regular & 2.48 & .54 & $2.30,2.65$ & \multirow{2}{*}{-11.087} & \multirow{2}{*}{57} & \multirow{2}{*}{.000} & \multirow{2}{*}{3.03} \\
\hline & Distance & 4.07 & .51 & $3.85,4.29$ & & & & \\
\hline \multirow[t]{2}{*}{ Social p. of $13-20$ year } & Regular & 3.25 & .43 & $3.10,3.39$ & \multirow{2}{*}{-1.387} & \multirow{2}{*}{55} & \multirow{2}{*}{.17} & \multirow{2}{*}{.35} \\
\hline & Distance & 3.52 & 1.00 & $3.09,3.92$ & & & & \\
\hline \multirow[t]{2}{*}{ Auto. of $13-20$ year } & Regular & 2.44 & .55 & $2.27,2.63$ & \multirow{2}{*}{-7.829} & \multirow{2}{*}{55} & \multirow{2}{*}{.000} & \multirow{2}{*}{2.08} \\
\hline & Distance & 3.73 & .69 & $3.46,4.02$ & & & & \\
\hline \multirow[t]{2}{*}{ Social p. of $>20$ year } & Regular & 3.33 & .68 & $3.12,3.55$ & \multirow{2}{*}{-2.80} & \multirow[b]{2}{*}{0} & \multirow{2}{*}{.007} & \multirow{2}{*}{.71} \\
\hline & Distance & 3.92 & .97 & $3.51,4.33$ & & & & \\
\hline \multirow[t]{2}{*}{ Auto. of $>20$ year } & Regular & 2.77 & .87 & $2.51,3.05$ & -6.843 & 60 & 000 & 194 \\
\hline & Distance & 4.16 & .52 & $3.93,4.37$ & & & & \\
\hline
\end{tabular}

\section{$4^{\text {th }}$ research question}

The level of study of the participants in the survey was arranged into three categories. In the first one there were assigned those who had a postgraduate degree (p.d.), in the second doctoral degree (d.d.) and in the third ones only the basic degree (b.d.). The t-test was used to check into the differences between the two teaching methods within each class of teaching experience.

Table 3

\begin{tabular}{|c|c|c|c|c|c|c|c|c|}
\hline \multirow{3}{*}{ Social p. of p.d } & Method & $\mathrm{M}$ & SD & BCa 95\% Cl & $\mathrm{t}$ & $d f$ & $\mathrm{p}$ & d \\
\hline & Regular & 3.24 & .60 & $3.11,3.44$ & \multirow{2}{*}{$-2,889$} & \multirow{2}{*}{84} & \multirow{2}{*}{.005} & \multirow{2}{*}{.619} \\
\hline & Distance & 3.74 & .89 & $3.44,4.04$ & & & & \\
\hline \multirow[t]{2}{*}{ Auto. of p.d } & Regular & 2.71 & .83 & $2.50,2.96$ & \multirow{2}{*}{-8.236} & \multirow{2}{*}{84} & \multirow{2}{*}{.000} & \multirow{2}{*}{$1.85 \mathrm{~s}$} \\
\hline & Distance & 4.08 & .63 & $3.85,4.29$ & & & & \\
\hline \multirow[t]{2}{*}{ Social p. of d.d } & Regular & 3.20 & .66 & $2.75,3.59$ & \multirow{2}{*}{-2.359} & \multirow{2}{*}{19} & \multirow{2}{*}{.029} & \multirow{2}{*}{1.042} \\
\hline & Distance & 4.04 & .93 & $3.50,4.51$ & & & & \\
\hline \multirow[t]{2}{*}{ Auto. of d.d } & Regular & 2.39 & .45 & $2.12,2.64$ & \multirow{2}{*}{-8.626} & \multirow{2}{*}{19} & \multirow{2}{*}{.000} & \multirow{2}{*}{3.847} \\
\hline & Distance & 4.14 & .47 & $3.85,4.40$ & & & & \\
\hline \multirow[t]{2}{*}{ Social p. of b.d } & Regular & 3.23 & .59 & $3.07,3.67$ & \multirow{2}{*}{-3.039} & \multirow{2}{*}{96} & \multirow{2}{*}{.003} & \multirow{2}{*}{.593} \\
\hline & Distance & 3.67 & .85 & $3.36,3.94$ & & & & \\
\hline \multirow[t]{2}{*}{ Auto. of b.d } & Regular & 2.46 & .57 & $2.34,2.61$ & \multirow{2}{*}{-12.267} & \multirow{2}{*}{96} & \multirow{2}{*}{.000} & \multirow{2}{*}{2.584} \\
\hline & Distance & 3.92 & .56 & $3.73,4.09$ & & & & \\
\hline
\end{tabular}

\section{Discussion - Conclusions}

The present study's first probing question looked into potential differences in the social presence and autonomy between the two teaching methods. The results indicated a significant difference between the two methods in the total sample, in statistical terms, both in the social presence 
index and the autonomy index, with the higher mean values to appear in the distance learning method. The abovementioned result coincides with the results of other surveys (Masino, 2015; Rubin et al., 2011; Sreebny, 2007; Huwe, 2006). The fact that the values in autonomy between the trainees in the distance learning method were high, may quite reasonably be interpreted, as this method actually requires a greater degree of autonomy. However, a noteworthy finding is the highest mean value of autonomy in distance learning compared to the regular learning method. It is may well be, that this result could be explained by the use of a variety of different communication tools available such as forums, chat, blogs, wikis, simulation software and e-mail; communication tools that were not been used in the regular training method. Certainly, this interpretation necessitates further empirical research.

As far as the differences within the group of men are concerned, those who attended the distance learning program introduced higher mean values in both social presence and autonomy than those who attended the regular method. That behaviour was not noticed in the women's group as far as the social presence is concerned. In this group, the autonomy featured a higher mean value in distance education, which was expected since, as spotted in the men's group as well as in the combined total of the sample, this is the figure that dominates.

In the third research question of this study, an investigation on the differences between the two methods regarding the teaching experience of the participants in the aggregate sample was performed. The results indicate there were no differences, neither in social presence nor in autonomy. The outcome was quite interesting, as we expected differences between the lessexperienced and those with greater experience in the field. Hence, differences in social presence and autonomy were searched for within each class of teaching experience. Based on the results, there were differentiations within the groups A up to 6 years and B from 21 years and over in the social presence, with the trainees participating in the distance education program presenting a higher mean value in the social presence. However, the above observation was not detected within groups A from 7 to 12 and B from 13 to 20 years old. An initial, socio-political, interpretation of this result is that teachers with 0 to 6 years of experience are not permanent but substitute teachers. This means that the participants have not attended the Introductory Training Program, which aims, among other, at the enhancement of the interpersonal relationship among the participants. The social presence, however, is strengthened by the development of interpersonal relationships and the ability to communicate in an environment of trust, such as the one of the distance education program (Garrison \& Akyol, 2009; p.24). Therefore, the participants in the distance education process were interacting, chatting and looking for friends (Papanikolaou, Gouli, \& Makri, 2013; p.247) without disregarding the educational process (Garrison \& Arbaugh, 2007) and their motivations for learning (Kucuk \& Sahin, 2013). Nevertheless, there is the Kim et al. (2011) study, which delves into the employment status (full time, part time) in relation to the social presence in distance education, where no significant relationship in statistical terms was noted. In the case of teaching instructors with more than 21 years of educational experience, the higher mean values of social presence in the distance educational method program may also be related to factors such as the interpersonal relationships they have developed in conjunction with their colleagues, combined with their age (Shea \& Bidjerano, 2009; p.548). Moreover, the older trainees and, hence, those having greater teaching experience, may have a stronger need to use the distance education tools (Poellhuber, Anderson, \& Roy, 2011; p.120) or to consider those distance education tools not only as means of communication, but as a kind of emotional bonding (So \& Brush, 2006), since technology in their undergraduate years was at an early stage.

The study of the autonomy factor in relation to the teaching experience, regarding the two teaching methods, presented relatively foreseeable results. Autonomy, as perceived in the aggregate sample as well, has a higher mean value in distance education and within each group of 
trainees, concerning their teaching experience. It is of great importance to document such an outcome, because by using it as a basis, a first comment can be made; in each age group of teachers, which corresponds to a group of educational experience, autonomy in distance education appears to have a leading role in the training process. At the same time, the corresponding mean value of autonomy in the regular teaching method, demonstrates values even lower than the mean value of our scale, an indication that, in this event, the sense of autonomy becomes sense of isolation. And even though self-management ability and monitoring of the learning process have gained a significant position in modern educational programs, as influential factors in distance education (Hartley \& Bendixen, 2001), there will always be participants among the trainees that will face significant difficulties in time management and learning rate and, in general, through the learning process of self-regulation skills (Chmiliar, 2011). Taking into account Al-Harthi's (2010) study, which focuses on self-regulation- a concept related to autonomy- in the learning process, in relation to the students' culture between two different educational systems, the American and the Arabic, we can assume that differences in autonomy may also be due to the different cultures of trainees within the Greek society itself, a conclusion, that most certainly, requires further study and a distinctive approach.

The findings that this study has brought out within the groups, regarding the level of study in the social presence of the two training methods are also noteworthy. In all three trainee groups, in terms of the level of education i.e. (a) holders of Master degrees, (b) holders of a $\mathrm{PhD}$ degree and (c) holders of graduate degree, social presence in distance education had a higher mean value than in the respective group of the in face to face teaching. This outcome is also consistent with studies that analyse the social presence in the level of studies (Kozan, 2016; Kožuh et al., 2015; Shin \& Chan, 2004), but it must be mentioned that there are studies with contrary results (Lee \& Choi, 2011; Berg \& Chyung, 2008). In conclusion, the necessity for further research regarding the social presence and its relation to the academic level of learners is evident, due to the fact that there is a contradiction and conclusions cannot be generalized. Factors such as the professional status of the trainees should form a discrete research field based on the above results, as they may stipulate this contradiction.

The conclusions that this study has reached with respect to the level of studies within the groups, as far as the autonomy is concerned in both the educational methods, are discussible. In all three groups of trainees, in terms of the level of studies, higher mean values in autonomy were observed in the distance education method. The statistical significance of the above results is also accompanied by the ascertainment that the mean values in autonomy, within the three groups, in the regular method of education, are below the average value of the scale, with the exception of a group of postgraduate degree holders, which seems to have a marginally higher value, that was also noted in the educational experience groups. It is possible, that this is related to the traits of the distance education like structure, conformation and the general form of the educational material as well as the role of the trainer-consultant (Nikolaki \& Koutsouba, 2013), features that enhance autonomy. (Peters, 2001; p.236). Moreover, one would expect a differentiation in the autonomy between the trainees with higher qualifications and others, with the first dominating in this comparison. That's because the acquisition of a postgraduate or a $\mathrm{PhD}$ degree is achieved through a process of personal effort which is being characterized by several degrees of freedom, in which the collaboration with the advisor is close but at the same time autonomous, the individual demonstrates critical thinking, research and self-examination skills (Gilmore et al., 2015). What we notice however in the group of trainees who only hold the basic qualification degree, is that there are differences in autonomy, with respect to the educational method.

In conclusion, this study demonstrates differences in the social presence and autonomy in both teaching methods, teaching experience and the level of study. However, some issues also emerged, which require further research that will validate the results or disprove them. 
In particular, it would be of interest to document the abovementioned indices in other training programs of the same group of trainee teachers, in order to detect the impact of the factor of the training subject. It would likewise be interesting to examine the above indices of social presence and autonomy in other professional teaching staff categories with the same level of education, either with the same research method or with elements from a qualitative method that might highlight other important parameters. Finally, it would be of importance to study the relationship between social presence and autonomy in teacher training programs concerning the educational outcomes of the training process within the school units.

\section{References}

1. Akcaoglu, M., \& Lee, E. (2016). Increasing Social Presence in Online Learning through Small Group Discussions. International Review of Research in Open and Distributed Learning, 17(3), 1-17.

2. Al-Harthi, A. (2010). Learner Self-Regulation in Distance Education: A Cross Cultural Study. The American Journal of Distance Education, 24(3), 135-150. Retrieved from http://dx.doi.org/10.1080/08923647.2010.498232

3. Anastasiadis, P. (2004). Open and Distance Learning Education - Main Principles Rethymno. Retrieved from http://www.edc.uoc.gr/ panas/UoCrete/VC\%20Dimotiko\%20Sxoleio/Notes\%20Vc/Mast er\%20DL3.doc

4. Anderson, T., \& Dron, J. (2011). Three Generations of Distance Education Pedagogy. International Review of Research in Open and Distance Learning, 12(3), 80-97.

5. Andrade, M. S. (2015). Teaching Online: A Theory-based Approach to Student Success. Journal of Education and Training Studies, 3(5), 1-9.

6. Antoniou, K., Volioti, Ch., \& Stilianidis, P. (2012). Distance learning cooperative activities: In a case study on Information and Communication Technologies in Education. In Ch. Karagiannidis, P. Politis, \& I. Karasavidis (Eds.), Volos: University of Thessaly.

7. Arvanitis, N. (2007). The portfolio as a means of alternative and authentic pedagogical evaluation of the student. Scientific Step, 6, 168-180.

8. Angelaki, C., \& Mavroidis, I. (2013). Communication and Social Presence: The Impact on Adult Learners' Emotions in Distance Learning. European Journal of Open, Distance and ELearning, 16(1), 78-93.

9. Balaban-Sali, J. (2008). Designing motivational learning systems in distance education. Turkish Online Journal of Distance Education, 9(3), 149-161.

10. Barnard, L., Lan, W., To, Y., Paton, V., \& Lai, S. L. (2009). Measuring self-regulation in online and blended learning environments. Internet and Higher Education, 12(1), 1-6.

11. Basdogan, C., Ho, C. H., Srinivasan, M., \& Slater, M. (2000). An experimental study on the role of touch in shared virtual environments. ACM Transactions on Computer-Human Interaction (TOCHI), 7(4), 443-460.

12. Benson, P. (2007). Autonomy in language teaching and learning. Language teaching, 40(1), 21 40.

13. Berg, S., \& Chyung, S. Y. (2008). Factors that Influence Informal Learning in the Workplace. Journal of workplace learning, 20(4), 229-244.

14. Bray, E., Aoki, K., \& Dlugosh, L. (2008). Predictors of Learning Satisfaction in Japanese Online Distance Learners. International Review of Research in Open and Distance Learning, 9(3). Retrieved from http://www.irrodl.org/index.php/irrodl/article/view/525/1154 
15. Chartofilaka, A-M. (2007). Towards a dynamic teaching tool for Distance Education. Open Education: The Journal for Open and Distance Education and Educational Technology, 3(2).

16. Chmiliar, L. (2011). Self Regulation skills and the post secondary distance learner. ProcediaSocial and Behavioral Sciences, 29, 318-321.

17. Christophel, D. M. (1990). The relationships among teacher immediacy behaviors, student motivation, and learning. Communication Education, 39, 323-340.

18. Christophel, D. M., \& Gorham, J. (1995). A test-retest analysis of student motivation, teacher immediacy, and perceived sources of motivation and demotivation in college classes. Communication Education, 44, 292-306.

19. Creswell, J. (2011). The study in Education (1 ${ }^{\text {st }}$ ed.). (Ch. Tzobartzoudis Ed., \& N. Kouvarakou, Trans.) Athens: Greece.

20. Driver, M. (2002). Exploring student perceptions of group interaction and class satisfaction in the web-enhanced classroom. Internet and Higher Education, 5(1), 35-45.

21. Falloon, G. (2011). Making the Connection: Moore's Theory of Transactional Distance and Its Relevance to the Use of a Virtual Classroom in Postgraduate Online Teacher Education. Journal of Research on Technology in Education, 43(3), 187-209.

22. Firat, M. (2016). Measuring the e-Learning Autonomy of Distance Education Students. Open Praxis, 8(3), 191-201.

23. Fotiadou, T. (2001). The portfolio as a tool for developing students' skills: A proposal. Education Review, 5, 128-138.

24. Garrison, D. R., \& Anderson, T. (2003). E-learning in the $21^{15}$ Century: A framework for research and practice. London: Routledge/Falmer.

25. Garrison, D. R., Anderson, T., \& Archer, W. (2000). Critical inquiry in a text-based environment: Computer conferencing in higher education. The Internet and Higher Education, 2, 87-105.

26. Garrison, R., \& Akyol, Z. (2009). Role of instructional technology in the transformation of higher education. Journal of Computing in Higher Education, 21(1), 19-31.

27. Garrison, R., \& Arbaugh, B. (2007). Researching the community of inquiry framework: Review, issues, and future directions. The Internet and Higher Education, 10(3), 157-172.

28. Ghamdi, A., Samarji, A., \& Watt, A. (2016). Essential Considerations in Distance Education in KSA: Teacher Immediacy in a Virtual Teaching and Learning Environment. International Journal of Information and Education Technology, 6(1), 17-22.

29. Giagli, S., Giaglis, G., \& Koutsouba, M. (2010). Autonomy in learning as it concerns the of distance learning education. Open Education - The Journal for Open and Distance Education and Educational Technology, 6(1-2), 90-105.

30. Gillies, D. (2008). Student perspectives on videoconferencing in teacher education at a distance. Distance Education, 29(1), 107-118.

31. Gilmore, J., Vieyra, M., Timmerman, B., Feldon, D., \& Maher, M. (2015). The relationship between undergraduate research participation and subsequent research performance of early career STEM graduate students. The Journal of Higher Education, 86(6), 834-863.

32. Gunawardena, C. N., \& Zittle, F. G. (1997). Social presence as a predictor of satisfaction within a computer mediated conferencing environment. American Journal of Distance Education, 11(3), 8-26. 
33. Hartley, K., \& Bendixen, L. D. (2001). Educational research in the Internet age: Examining the role of individual characteristics. Educational Researcher, 30(9), 22-26.

34. Hurd, S., Beaven, T., \& Ortega, A. (2001). Developing autonomy in a distance language learning context: issues and dilemmas for course writers. System, 29(3), 341-355.

35. Huwe, T. K. (2006). Social networking mixes the hip with the proven. Computers in Libraries, 26(10), 31-33.

36. Karava, E. (2014). Developing an online distance training programme for primary EFL teachers in Greece: Entering a brave new world. Research Papers in Language Teaching and Learning, 5(1), 70-86.

37. Kastanos, N., Petropoulos, P., \& Roussis, R. (2004). Design proposal for the design of decentralized distance learning programs for teachers in the teaching of natural sciences. Paper presented at the $2^{\text {nd }}$ Conference of the Association for Natural Science Teaching and $2^{\text {nd }}$ IOSTE in Southern Europe concerning the Teaching Science \& Technology: Challenges of the $21^{\text {st }}$ Century. Kalamata.

38. Kear, K. (2010). Social presence in online learning communities. Proceedings of the $7^{\text {th }}$ International Conference on Networked Learning 2010. Denmark.

39. Keegan, D. (1996). Foundations of Distance education ( $3^{\text {rd }}$ ed.). London: Routledge.

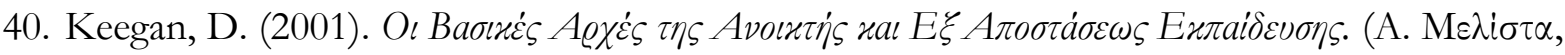

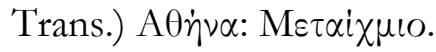

41. Kim, J., Kwon, Y., \& Cho, D. (2011). Investigating factors that influence social presence and learning outcomes in distance higher education. Computers \& Education, 57, 1512-1520.

42. Komis, B., Zagouras, Ch., Eggarchou, D., Skountzis, G., Goumenakis, G., Simotas, K., \& Fragkaki, M. (2014). The conceptual design of the mixed education model for primary school teachers (UE 60-70). In P. Anastasiadis, N. aranis, B. Oikonomidis \& M. Kalogiannakis (Eds.), $9^{\text {th }}$ Pan-Hellenic Conference with International Participation in Information and Communication Technologies in Education (pp. 1025-1032). Rethymnon: University of Crete.

43. Kozan, K. (2016). A Comparative Structural Equation Modeling Investigation of the Relationships among Teaching, Cognitive and Social Presence. Online Learning Consortium, 20(3), 210-227.

44. Kožuh, I., Hintermair, M., Hauptman, S., \& Debevc, M. (2015). What predicts the frequencies of activities on social networking sites among the D/deaf and hard of hearing. Procedia Computer Science, 67, 185-192.

45. Kucuk, S., \& Sahin, I. (2013). From the Perspective of Community of Inquiry Framework: An Examination of Facebook Uses by Pre-Service Teachers as a Learning Environment. Turkish Online Journal of Educational Technology - TOJET, 12(2), 142-156.

46. Lazakidou-Kafetzi, G., Paraskeva, F., \& Retalis, S. (2004). By detecting ways of using metacognitionfor to mathematical problems solution. Proceedings of the $4^{\text {th }}$ HSCSE Congress, 143-152. Athens.

47. Lee, Y., \& Choi, J. (2011). A review of online course dropout research: implications for practice and future research. Education Tech Research, 59, 593-618. doi: 10.1007/s11423-010$9177-\mathrm{y}$

48. Li, N., Lee, K., \& Kember, D. (2000). Towards self-direction in study methods: The ways in which new students learn to study part-time. Distance Education, 21(1), 6-28. 
49. Lionarakis, A. (2001). Which Distance Learning Education we are talking for? Concerning the records of the $1^{\text {st }}$ Panhellenic Conference for Open and Distance Learning Education. Hellenic Open University of Patra.

50. Lionarakis, A. (2004). Towards a theory of Open and Distance Learning Education - the development of complexity. Retrieved from TEI of Larissa: http://elektra.teilar.gr/syncppt/theoryOfTeleeducation.pdf

51. Lionarakis, A. (2009) Developing a Methodological Approach (Teaching) of Lifelong Learning Programs from distance. Athens: Institute for Adult Education.

52. Lombard, M., \& Ditton, T. (1997). At the heart of it all: The concept of presence. Journal of Computer-Mediated Communication, 3(2). Retrieved from http:/ /onlinelibrary.wiley.com/doi/10.1111/j.1083-6101.1997.tb00072.x/full

53. Lombard, M., Ditton, T. B., Crane, D., \& Davis, B. (2000). Measuring presence: A literaturebased approach to the development of a standardized paper-and-pencil instrument. Proceedings of the Third international workshop on presence, 240, 2-4. Netherlands.

54. Masino, M. (2015). Integration of blackboard in the online learning environment. Journal of Instructional Pedagogies, 16. Retrieved from http:// files.eric.ed.gov/fulltext/EJ1069393.pdf

55. Moore, A., Masterson, J. T., Christophel, D. M., \& Shea, K. A. (1996). College teacher immediacy and student ratings of instruction. Communication Education, 45, 29-39.

56. Moore, M. G. (2016). Thirty Years Later: Self-Directed Learning and Distance Education-In Retrospect. International Journal of E-Learning \& Distance Education, 31(2). Retrieved from http://ijede.ca/index.php/jde/article/view/1000/1656

57. Moore, G. M., \& Kearsley, G. (2005). Distance Education. A Systems View (2 ${ }^{\text {nd }}$ ed.). Canada: Thomson Wadsworth.

58. Mouzakis, C., \& Balaouras, P. (2009). Real-time Video Services for Continuing Professional Development of the Greek Academic Network's Technical Staff. In T. Bastiaens (Ed.), Proceedings of World Conference on E-Learning in Corporate, Government, Healthcare, and Higher Education (pp. 1836-1841). Chesapeake: VA: AACE.

59. Mouzakis, Ch., Vathis, S., \& Gogolou, A. (2014). Learning experiences through online discussions: Making use of Edmodo in distance education of teachers. Science and Technology Issues in Education, 7(1-2), 77-97.

60. Nikolaki, E., \& Koutsouba, M. (2012). Support and promotion of self-regulated learning through the educational material at the Hellenic Open University. Turkish Online Journal of Distance Education-TOJDE, 13(3), 226-238.

61. Noteboom, J., \& Claywell, L. (2010). Student Perceptions of Cognitive, Social, and Teaching Presence. Proceedings of the $26^{\text {th }}$ Annual Conference on Distance Teaching \& Learning, 1-4.

62. Nowak, K., \& Biocca, F. (2003). The Effect of the Agency and Anthropomorphism on Users' Sense of Telepresence, Copresence, and Social Presence in Virtual Environments. Massachusetts Institute of Technology, 12(5), 481-494.

63. Ntalakou, B. P. (2005). Application of learning through problem solving in distance education: Detection of student's views on the administrative organization in Greece. In A. Lionarakis (Ed.), Applications of Pedagogy and Technology. Records Kept of the $3^{\text {rd }}$ International Conference concerning the Open and Distance Education (pp. 317-325). Athens: Forerunner (Propobos). 
64. Offir, B., Lev, Y., \& Bezalel, R. (2008). Surface and deep learning processes in distance education: Synchronous versus asynchronous systems. Computers \& Education, 51(3), 11721183.

65. Pantis, I. (2016). Compulsory laboratory activities of Physical Sciences in High Schools, General Lyceums and Vocational High Schools. For the school year 2015-2016. Marousi: Ministry of Education Research and Religious Affairs. Retrieved from https://www.minedu.gov.gr/publications/docs2016/26-01-16_ergastiriakes.pdf

66. Papanikolaou, K., Giouli, E., \& Makri, K. (2013). A mixed teacher education framework concerning the teaching of digital technology. Proceedings of the $7^{\text {th }}$ International Conference in Open \& Distance Learning, 7, 243-255. Athens.

67. Papastamatis, A., Grivas, E., Valkanos, E., \& Giavrimis, P. (2010). Professional development of teachers: Teachers' needs in Second Chance Schools and suggested training methods. (K. Afoi, Ed.) Thessaloniki.

68. Paraskevas, A., \& Psilos D. (2009). Research of the active participation and interaction of teachers, in their distance education cooperation in the context of their training in the area of fluids. Open Education - The Journal for Open and Distance Education and Educational Technology, 5(1), 64-76.

69. Paulsen, M. F. (1993). The hexagon of cooperative freedom: A distance education theory attuned to computer conferencing. Distance Education Online Symposium, 3(2).

70. Peters, O. (2001). Learning and teaching in distance education: Analyses and interpretations from an international perspective. London: Kogan Page.

71. Peters, O. (2010). Distance education in transition: Developments and issues ( $5^{\text {th }}$ ed.). Oldenburg, Germany: BIS-Verlag der Carl von Ossietzky Universität Oldenburg. Retrieved from https://www.unioldenburg.de/fileadmin/user_upload/c31/master/mde/download/asfvolume5_5_ebook.pdf

72. Poellhuber, B., Anderson, T., \& Roy, N. (2011). Distance students' readiness for social media and collaboration. International Review of Research on Distance and Open Learning, 12(6), 102-125. Retrieved from http://www.irrodl.org/index.php/irrodl/article/viewFile/1018/1992

73. Richardson, C., \& Swan, K. (2003). Examining social presence in online courses in relation to students' perceived learning \& satisfaction. Journal of Asynchronous Learning Networks, 7(1), 6888.

74. Rovai, A. P. (2002). Development of an instrument to measure classroom community. Internet and Higher Education, 5(3), 197-211.

75. Rubin, B., Fernandes, R., \& Avgerinou, M. (2011). How the Use of Virtual Learning Environment Tools Affects the Online Learning Experience? Proceedings of the $6^{\text {th }}$ International Conference in Open \& Distance Learning, 595-601. Loutraki.

76. Schubert, T. W., Friedmann, F., \& Regenbrecht, H. T. (1999). Decomposing the sense of presence: Factor analytic insights. Proceedings of the $2^{\text {nd }}$ International Workshop on Presence, 6-7. University of Essex.

77. Shea, P., \& Bidjerano, T. (2009). Community of inquiry as a theoretical framework to foster "epistemic engagement" and "cognitive presence" in online education. Computers \& Education, 52, 543-553.

78. Shearer, R. (2007). Instructional Design in Distance Education: An Overview. In M. Moore, \& W. Anderson (Eds.), Handbook of distance education (pp. 275-286). London: Lawrence Erlbaum Associates, Inc., Publishers. 
79. Shin, N., \& Chan, J. (2004). Direct and indirect effects of online learning on distance education. British Journal of Educational Technology, 35(3), 275-288.

80. Sibgatullina, A. (2015). Contemporary Technologies to Improve the Quality of Education When Training Teachers. International Education Studies, 8(3), 167-174.

81. Simonson, M., Smaldino, S., \& Albri, M. (2008). Teaching and Learning at a Distance Foundations of Distance Education ( $4^{\text {th }}$ ed.).

82. Smith, C. (2007). When in Rome: Teaching $21^{\text {st }}$ century students using $21^{\text {st }}$ century tools. Proceedings of the $12^{\text {th }}$ Annual Instructional Technology Conference, 3, 3-20. Murfreesboro. Retrieved from http:/ / files.eric.ed.gov/ fulltext/ED496202.pdf\#page=3

83. So, H.-J., \& Brush, T. (2006). Student perceptions of cooperative learning in a distance learning environment: Relationships with social presence and satisfaction. Annual Meeting of the American Educational Research Association (AERA), 1(1).

84. So, H., \& Brush, T. (2008). Student perceptions of collaborative learning, social presence \& satisfaction in a blended learning environment: Relationships \& critical factors. Computers \& Education, 51(1), 318-336.

85. Sreebny, O. (2007). Digital rendezvous: Social software in higher education. EDUCAUSE Center for Applied Research, 2.

86. Steuer, J. (1992). Defining Virtual Reality: Dimensions Determining Telepresence. Journal of Communication, 42(4), 72-93.

87. Sung, E., \& Mayer, R. E. (2012). Five facets of social presence in online distance education. Computers in Human Behavior, 28(5), 1738-1747.

88. Tam, M. (2000). Constructivism, Instructional Design, and Technology: Implications for Transforming Distance Learning. Educational Technology \& Society, 3(2), 50-60.

89. Themeli, C., \& Bougia, A. (2016). Tele-proximity: Tele-community of Inquiry Model. Facial Cues for Social, Cognitive, and Teacher Presence in Distance Education. International Review of Research in Open and Distributed Learning, 17(6), 145-163.

90. Tsiotakis, P., \& Tzimogiannis, A. (2014). The role study of the Structure in the Development of Electronic Learning Communities of Teachers. In P. Anastasiadis, N. Zaranis, V.

Oikonomidis, \& M. Kalogiannakis (Eds.), $9^{\text {th }}$ PanHellenic Conference with International Participation: Technologies of Information \& communication in Education (pp. 309-318). Rethymno: University of Crete.

91. Tsitlakidou E. (2011). The role of the teacher concerning the autonomy in learning for distance education learners. Postgraduate Thesis, Open University of Patra, Studies in Education, Patra.

92. Witmer, B. G., \& Singer, M. J. (1998). Measuring Presence in Virtual Environments: A Presence Questionnaire. (MIT, Ed.) Presence, 7(3), 225-240. 